\title{
Oral hygiene and oral health status of the nursing students in Turkey
}

\section{Mehmet Vehbi BAL (*), Umut BENGi (*), Cengizhan AÇIKEL $\left({ }^{* *}\right)$, IşıI SAYGUN $\left({ }^{*}\right)$}

\begin{abstract}
ÖZET
Türkiyedeki hemşirelik öğrencilerinin ağız sağlığı ve ağız sağlık durumları

Bu çalışmada, Türkiye'nin beş farklı demografik bölgesinde ki kız öğrenci populasyonunu temsil eden, hemşirelik okulu öğrencilerinin, ağız hijyeni ve ağız sağlığı durumlarının belirlenmesini amaçladık. Gülhane Askeri Tıp Akademisi Hemşirelik Yüksek Okulundaki (18-22 yaşlarında) üç yüz yirmi beş kız öğrenci çalışmaya dahil edildi. Öğrencilerin ağız içi muayeneleri yapıldı, genel tıbbi öyküleri ve oral hijyen uygulamalarına ilişkin görüşüldü. Öğrencilerin sadece küçük bir kısmı (\%4.6) sigara kullanıyordu. Plak kontrolü \%82.8'inin çok iyi ve \%17.2'sinin iyiydi. Bununla birlikte, öğrencilerdeki diş çürükleri ve sonuçları, yüksek çürükeksik-dolgulu diş (decayed missing filled tooth) skoru değerleri ile nispeten yaygın bir sorundu. Dentin hassasiyeti \%32.9'unda saptandı. Öğrencilerin 13'üne (\%4) periodontitis tanısı konuldu. Öğrencilerin küçük bir yüzdesinde Orta (\%6.5) veya şiddetli (\%0.6) gingivitis görülürken hafif gingivitis (\%35.1) oldukça yaygındı. Ağız hijyeni davranışları hemşirelik öğrencilerinin bu grubunda oldukça iyiydi. Bununla birlikte, diş çürükleri, hafif gingivitis ve dentin hassasiyeti öğrenci populasyonunu etkileyen ortak sorunlardandı. Bu bulguları ortadan kaldırmak için ağız sağlığı
\end{abstract} programları ve rutin diş hekimi ziyaretleri teşvik edilmelidir.

Anahtar Kelimeler: Diş sağlığı araştırması, ağız sağlığı durumu, periodontal durum, periodontal hastalık prevalansı.

SUMMARY

In this study we aimed to determine oral hygiene behavior and oral health status of the students at the nursing school in Turkey, with a female student population representative of five different demographical regions of Turkey. Three hundred and twenty five female students (aged 18-22 years) of Gulhane Military Medical Academy, School of Nursing were included in the study. Intraoral examination was performed and students were interviewed regarding general medical history and oral hygiene practices Only a minority of students were smokers (4.6\%). Plaque control efficacy was very good in $82.8 \%$ and good in $17.2 \%$ of the students. The presence of dental caries and its outcomes were relatively common problems presenting with high decayed missing filled tooth scores of students. Dentin hypersensitivity was present in $32.9 \%$. Periodontitis was diagnosed in 13 students (4\%). Mild gingivitis was fairly common $(35.1 \%)$, while moderate $(6.5 \%)$ or severe $(0.6 \%)$ gingivitis was seen in a small percentage of students. Oral hygiene behavior was fairly decent in this group of nursing students. Nevertheless, dental caries, mild gingivitis and dentin hypersensitivity were common problems affecting the student population. Oral healthcare programs and routine dentist visits should be encouraged to counteract these findings.

Key Words: Dental health survey, oral health status, periodontal status, periodontal disease prevalence
*Department of Periodontology, Gulhane Military Medical Academy, Ankara, Turkey

** Department of Public Health, Gulhane Military Medical Academy, Ankara, Turkey.

Ayrı basım isteği: Mehmet Vehbi BAL

Gulhane Military Medical Academy,

Department of Periodontology,

Etlik Caddesi, Ankara, 06018 Turkey

E-mail:vehbibal@hotmail.com

Makalenin Geliş Tarihi: 14.03.2014 • Kabul Tarihi: 23.06.2014 • Çevrim Içi Basım Tarihi: 25.10.2015

\section{Introduction}

Oral health has a high impact on general health, quality of life, self-image and well-being. Oral diseases such as dental caries, periodontal disease and tooth loss continue to be major public health problems contributing to the global burden of disease. Global epidemiological surveys conducted by World Health Organization (WHO) show that dental caries is present in nearly $100 \%$ of adults, with a high decayed missing filled tooth (DMFT) score (14 or more teeth) seen in 35-44 yearolds in most industrialized countries. The prevalence of dental caries among children is increasing in developing countries, and decreasing in developed countries, with a mean DMFT of 2.6 in Europe. Worldwide, severe periodontitis affects $5-20 \%$ of adults, while aggressive periodontitis affects about $2 \%$ of young people and gingivitis is present in most children and adolescents (1).

Traditionally the focus of oral health has been on restoration and pain relief with little emphasis on preventive oral care programs. However, restorative care is expensive increasing the oral health gap between socioeconomically privileged people and disadvantaged people. Thus preventive oral health needs to be promoted and national programs should be implemented to educate people (2). Studies in Turkey show that patients are inconsistent in their knowledge and oral health behavior, and there is an unmet need for oral health education by professionals (3). Considering that nurses, as professional healhcare workers, have an active role in maintaining oral health of patients in their care and could serve as role models promoting oral health and disease prevention, it is important to determine their oral health behaviors so as to establish interventions to prepare them for their future role in public health. In spite of this fact, nurses' oral health behoviors and attitudes have not been studied so far.

Therefore, in this study we aimed to determine oral hygiene behavior and oral health status in nursing schools, with a female student population representative of five different demographical regions of Turkey.

\section{Material and Methods}

Three hundred and twenty five female students (aged 18-22 years) of Gulhane Military Medical Academy, School of Nursing were included in a survey of oral hygiene and periodontal health. School of nursing provided a representative cohort of young educated Turkish women, as students came to study nursing from five demographical regions of Turkey according to Classification of Turkey Istatistical Region Unit by TUIK (http://www.turkstat.gov.tr/). Figure 1 shows distribution of 
nursing students according to regions. All students were examined by the same periodontist in the Periodontology Department, Institute of Dental Sciences, Gulhane Military Medical Academy. A questionnaire regarding general medical history and oral hygiene practices was filled during a face-to-face interview. Intraoral examination was conducted under reflector light, using mirror, explorer probe and periodontal probe (Williams periodontal probe, Kohdent-Kohler, Germany, 3106). Panoramic and/or periapical radiography was not performed unless necessary. Students requiring dental or periodontal treatment were directed to appropriate departments regarding their treatment needs.

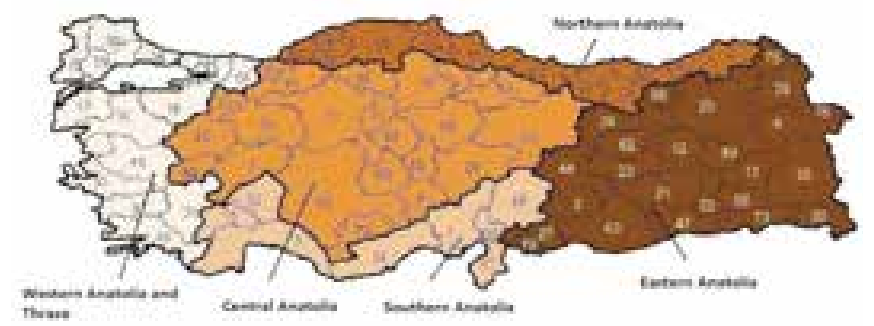

Figure 1. Nursing students came from five different demographical regions of Turkey: Western Anatolia and Thrace, Central Anatolia, Southern Anatolia, Northern Anatolia and Eastern Anatolia (Classification of Turkey Istatistical Region Unit by TUIK, http://www.turkstat.gov.tr/).

Full-mouth periodontal examination was conducted and the results were expressed using plaque index (PI) (4), gingival index (5), bleeding on probing (BOP) percentage, probing depth (PD), gingival recession (GR), and clinical attachment level (CAL).

Periodontitis was defined as BOP> $50 \%, C A L \geq 2 \mathrm{~mm}, \mathrm{PD} \geq$ $5 \mathrm{~mm}$ in one or more surfaces of two or more teeth.

Severity of gingivitis was determined by the rate of BOP (0$24.99 \%$, healthy; $25-49.99 \%$, mild gingivitis; $50-74.99 \%$, moderate gingivitis; $75-100 \%$, severe gingivitis).

Decayed missing filled tooth (DMFT) and decayed missing filled tooth surfaces (DMFTs) indexes were used as oral status indicators. Erupted or not third molars were not included. DMFT index calculated without radiograph. All 28 teeth were examined; teeth which were not included were third molars, unerupted teeth, congenitally missing and supernumerary teeth and teeth which were removed for other reasons than dental caries such as trauma, cosmetic purposes or for use as bridge abutments. The overall DMFT value was obtained as a sum of the decayed, missing and filled teeth for each patient. The DMFT index is generally expressed as the average number of DMF teeth per person in the population which is being studied (6).

\section{Statistics}

SPSS 19.0 software package (SPSS Inc., Chicago, IL, USA) was used in the statistical analysis. Normality analyses were performed by One Sample Kolmogorov Smirnov test. Comparisons of continuous variable were conducted by Kruskal Wallis test, and Bonferroni corrected Mann Whitney $U$ test was used as post-hoc te st. Correlation analysis was performed using Spearman correlation. Level of significance was set at $p<0.05$.

\section{Results}

All 325 attending students of the nursing school were included in the study. All students were women, between 18 and 22 years of age (20 \pm 2 years). Demographically, 116 students came from region 1 (Western Anatolia and Thrace), 99 students came from region 2 (Central Anatolia), 50 students came from region 3 (Southern Anatolia), 38 students came from region 4 (Northern Anatolia) and 22 students came from region 5 (Eastern Anatolia) (Figure 1).

Overall oral hygiene was adequate, with $88.9 \%$ of the students brushing their teeth two or more times a day, although use of dental floss, interdental toothbrush or mouth rinse was rare (Table I). Only a minority of students were smokers (4.6\%). Dentin hypersensitivity, halitosis and open-mouth breathing were common complaints.

$\begin{array}{ll} & \\ \text { Table I. Oral hygiene behavior and medical history } & \\ & \% \\ \text { Tooth brushing frequency (once / } \geq 2 \text { a day) } & 11.1 \text { / 88.9 } \\ \text { Dental floss use (regular / irregular) } & 1.5 \text { / } 4.3 \\ \text { Interdental toothbrush use (regular / irregular) } & 1.2 \text { / } 0.9 \\ \text { Mouth rinse use } & 0.3 \\ \text { Chewing } & 22.8 \\ \text { Smoking } & 4.6 \\ \text { Dentin hypersensitivity } & 32.9 \\ \text { Halitosis } & 17.8 \\ \text { Open mouth breathing } & 17.8 \\ \text { Dry mouth } & 7.1 \\ \text { Bruxism } & 8.6 \\ \text { Orthodontic malocclusion } & 12.9 \\ \text { Temporomandibular joint complaint } & 1.2 \\ \text { History of orthodontic treatment } & 11.4 \\ \text { Systemic disease } & 4.3 \\ \text { Regular drug use } & 2.5 \\ \text { Systemic disease in the family } & 26.8 \\ \text { Early tooth loss in the family } & 12.0\end{array}$

Mean values of periodontal and dental caries indexes are presented in (Table II). Overall plaque control efficacy was sufficient in all students (Figure 2A). However, dental caries was highly prevalent as $81.2 \%$ had a DMFT score $>0$. DMFT score was moderate or higher $(\geq 2.7)$ in $63 \%$ of the students (Figure $2 \mathrm{~B})$. The mean number of decayed tooth $(1.83 \pm 2.27)$ accounted for nearly half of the mean DMFT score $(4.26 \pm 3.58$, Table II). BOP percentage was moderate in $34.8 \%$ and high in $22.5 \%$ (Figure 2C). Caries prevalence did not differ between demographical regions or junior/senior years.

\begin{tabular}{|c|c|c|}
\hline & Min-Max & Mean \pm SD \\
\hline Plaque index & $0.13-1.87$ & $0.79 \pm 0.26$ \\
\hline Gingival index & $0.04-1.97$ & $0.71 \pm 0.43$ \\
\hline BOP (\%) & $1.61-91.96$ & $26.87 \pm 17.25$ \\
\hline PD & $1.43-3.17$ & $2.08 \pm 0.24$ \\
\hline CAL & $1.43-3.17$ & $2.09 \pm 0.24$ \\
\hline DMFT & $0-19$ & $4.26 \pm 3.58$ \\
\hline No. of decayed tooth & $0-9$ & $1.83 \pm 2.27$ \\
\hline DMFS & $0-28$ & $4.94 \pm 4.46$ \\
\hline No. of decayed tooth surface & $0-15$ & $1.98 \pm 2.51$ \\
\hline
\end{tabular}

BOP, bleeding on probing; PD, periodontal pocket depth; CAL, clinical attachment loss; DMFT, Decayed missing filled tooth; DMFS, Decayed missing filled tooth surfaces 

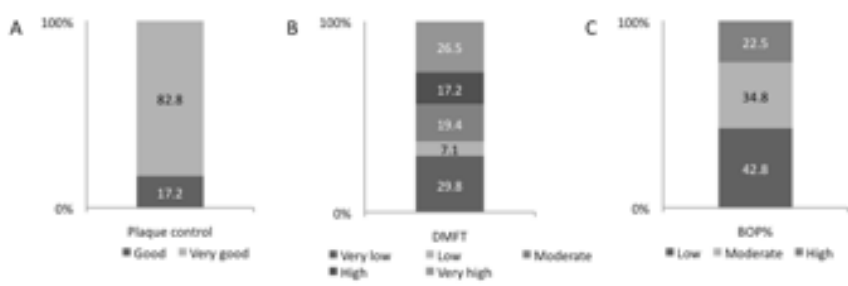

Figure 2. Intraoral examination results. A, Plaque control efficacy, according to the plaque index $(\mathrm{PI})$ by Silness \& Loe, $\mathrm{PI}$ index scores categorized as very good (0-0.99), good (1-1.99), bad (2-2.99) and very bad (4,5); B, DMFT index scores categorized as very low (0.0-1.1), low (1.2-2.6), moderate (2.7-4.4), high (4.5-6.5) and very high (>6.5); C) BOP percentage categorized as low, moderate and high.

Periodontitis was diagnosed in 13 students $(4.0 \%)$, while 21 had moderate gingivitis (6.5\%), 114 had mild gingivitis $(35.1 \%)$, and 175 had healthy gingiva (53.8\%, Figure 3$)$. Periodontal health did not differ between demographical regions (Figure 4) or junior/senior years. There was no significant correlation between gingivitis/periodontitis and DMFT categories $(p=0.940)$. Similarly, gingivitis/periodontitis was not associated with halitosis $(p=0.755)$.

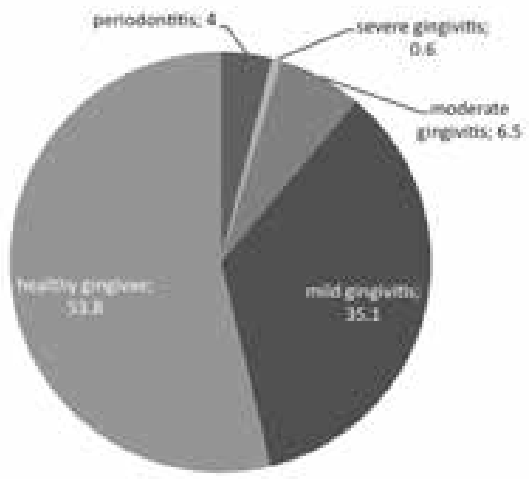

Figure 3. Prevalence of periodontitis and gingivitis in the student population. Periodontitis was defined as $\mathrm{BOP}>50 \%, \mathrm{CAL} \geq 2 \mathrm{~mm}, \mathrm{PD} \geq 5 \mathrm{~mm}$ in one or more surfaces of two or more teeth. Gingivitis severity was classified into four groups according to BOP scores: healthy gingiva (0-24.99\%), mild gingivitis (25$49.99 \%)$, moderate gingivitis (50-74.99\%), severe gingivitis $(75-100 \%)$.

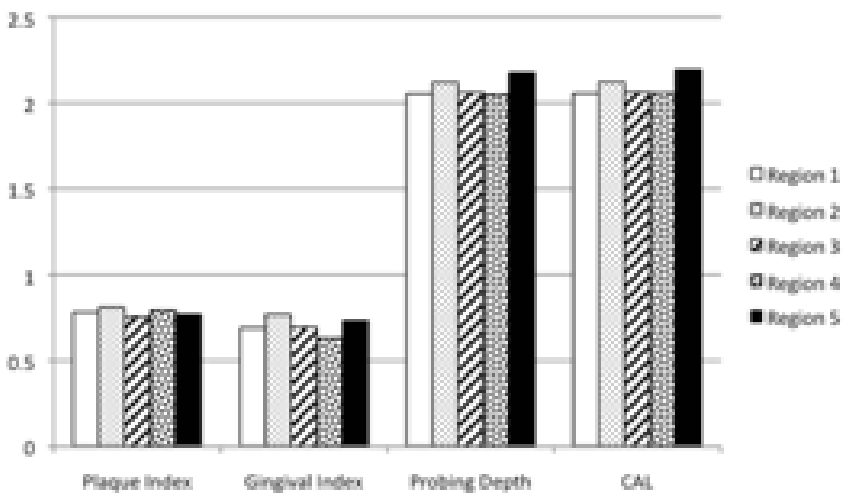

Figure 4. Periodontal status of nursing students by demographical region: region 1, Western Anatolia and Thrace; region 2, Central Anatolia; region 3, Southern Anatolia; region 4, Northern Anatolia; region 5, Eastern Anatolia.

\section{Discussion}

The present study showed that Turkish nursing students, potential key healthcare professionals to education society on oral health, had adequate oral hygiene behavior, but majority had at least one tooth affected by caries. Still, with good planning and continuous education programs, nurses can effectively participate in public health activities on dental care.

Epidemiological studies and pathfinder surveys are important tools in assessment of healthcare-related needs in a population. In Turkey nationwide oral health-related surveys show an urgent need for community-based oral disease prevention programs (7). As healthcare professionals, nurses are in a unique position to inform and educate the public regarding oral health and even perform oral health assessments in a variety of settings $(8,9)$. Thus, we aimed to assess oral self-care behaviors and oral health condition of nursing students and emphasize their future role in public oral health.

We found that nursing students had adequate oral hygiene behavior, with $88.9 \%$ brushing their teeth two or more times a day and all students having sufficient plaque control, more favorable results than that of previous studies. In comparison, in a study evaluating oral hygiene behavior of Turkish dental students, the prevalence of tooth brushing two or more times a day was $78.2 \%$ for females, $68.4 \%$ for males and $74.1 \%$ overall (10). Dental students showed improved oral hygiene in clinical years of study, compared to the preclinical years (10, 11), while no such difference was observed among senior and junior year students in our study. In another oral self-care survey with college students from 19 Mayis University in Samsun, Turkey, the prevalence of brushing twice daily or more was $83 \%$ for females and $49 \%$ for males ( $p<0.001)(12)$. These studies on young adults with higher education reflect much better oral hygiene behaviors than the national average, since $15 \%$ of adults did not own a toothbrush and only half of toothbrush owners used it on a daily basis in the most recent national survey in Turkey (7).

Smoking was reported by $4.6 \%$ of the students in our study. In contrast, $14.1 \%$ of female dental students and $33.3 \%$ of male dental students were smokers in the 2009 study by Peker et al (10). Although smoking is less prevalent among women, the rate reported in our study group is exceptionally low. Public anti-smoking campaigns implemented in Turkey in the past few years may have had a positive effect on the smoking rate, although no studies have been published to determine the impact of these campaigns yet.

Factors such as past caries experience, socioeconomic status, fluoride exposure, teeth morphology and microbial agents determine the risk of caries in adults and children (13). Despite seemingly adequate oral hygiene behaviors, efficient plaque control and non-smoking, majority of nursing students in this study $(81.2 \%)$ had at least one tooth affected by caries (DMFT $\geq 1$ ), and mean DMFT score was 4.26. However, this DMFT score is lower compared to caries prevalence determined in other Turkish studies on similar age groups. In a study of Turkish adults agreeing to get a free dental examination in Bayrampasa district of Istanbul, mean DMFT was 4.96 in 1819 year-olds and 5.7 in 20-24 year-olds (14). In a study of 20 year-old Turkish military recruits mean DMFT was 5.97 (15). When compared with similar age groups from other countries, DMFT score of nursing students in this study was worse than Italian call-up soldiers (3.69), similar to Spanish medical students (4.33), and better than Spanish dental students (5.91), 
Israeli army recruits (6.77) and Hungarian police students (10.3) (16-19). In Turkey a national survey conducted in 20042005 had found a steep increase in DMFT scores, which averaged at 2.3 in 15 year-olds, 10.8 in 35-44 year-olds, and 25.8 in 65-74 year-olds (7).

Periodontal disease is an inflammatory condition which may eventually lead to tooth loss and decreased quality of life. Prevalence of periodontal disease appears to increase in high-income countries but this seems to be largely due to the increased number of people with advanced age retaining their natural teeth (20). In contrast, aggressive periodontitis affects mostly young people and leads to rapid deterioration of periodontal tissue. There are several definitions for periodontitis in adolescents and young adults, affecting the reported prevalence considerably (21). In this study we defined BOP> $50 \%, C A L \geq 2 \mathrm{~mm}, \mathrm{PD} \geq 5 \mathrm{~mm}$ in one or more surfaces of two or more teeth as periodontitis. Using this criteria, periodontitis was identified in $4 \%$ of the nursing students. Using stricter criteria which included radiographically determined bone loss around the first molars bilaterally, Eres et al., found the prevalence of local aggressive periodontitis as $0.6 \%$ among Turkish teenagers 13-19 years of age (22).

In this study more than half of the students had healthy gingiva, and approximately one third had mild gingivitis. In the national survey by Gokalp, $56 \%$ of 15 -year-old population had healthy periodontal tissue, while most $35-44$ year-olds $(63 \%)$ had gingival bleeding and calculus problems (7). On the other hand, Turkish data from WHO global oral health databank showed healthy periodontal tissue in only $26 \%$ of $15-19$ yearolds, while $51 \%$ had gingival bleeding and $21 \%$ had gingival bleeding and calculus (20).

When all results considered, we presented the oral hygiene behavior and oral health status of Turkish nursing students as we intended. Overall results revealed that female nursing students in this study had considerably better oral hygiene behavior than the average Turkish people in national surveys. This is an expected finding depending on their healthcare-related training. However, dental caries and gingivitis were still common problems among nursing students.

In conclusion, although dental caries and gingivitis are still common problems, nursing students have a favorable oral hygiene behavior. Therefore, nurses are potential candidates who can participate in education of the public regarding oral health and even performing oral health assessments. Due to their unique position in healthcare practice and wide range of working areas including rural regions, nurses have critical role public health. Further studies evaluating the practice of nurses in public dental healthcare are needed to determine the content of in-training education of nurses and to implent planned public education programs by nurses.

The authors declare that they have no conflict of interest.

\section{References}

1. Petersen PE, Bourgeois D, Ogawa H, EstupinanDay S, Ndiaye C. The global burden of oral diseases and risks to oral health. Bull World Health Organ. 2005; 83: 661-669.
2. Petersen PE. World Health Organization global policy for improvement of oral health--World Health Assembly 2007. Int Dent J. 2008; 58: 115-121.

3. Uysal S, Akalin FA, Yamalik N, Etikan I. Unmet need for education by professionals and inconsistency in knowledge and behavior of dental patients. N Y State Dent J. 2010; 76: 16-21.

4. Silness J, Löe H. Periodontal disease in pregnancy II. Correlation between oral hygiene and periodontal condition. Acta Odontologica. 1964; 22: 121135.

5. Löe H, Silness J. Periodontal disease in pregnancy I. Prevalence and severity. Acta Odontologica. 1963; 21: 533-551.

6. Swapna LA, Reddy RS, Ramesh T, Reddy RL, Vijayalaxmi N, Karmakar $P$, Pradeep K. Oral health status in haemodialysis patients. J Clin Diagn Res. 2013; 7: 2047-2050.

7. Gokalp SG, Dogan BG, Tekcicek MT, Berberoglu A, Unluer S. National survey of oral health status of children and adults in Turkey. Community Dent Health. 2010; 27: 12-17.

8. Clemmens D, Rodriguez K, Leef B. Knowledge, attitudes, and practices of baccalaureate nursing students regarding oral health assessment. J Nurs Educ. 2012; 51: 532-535.

9. Fulmer $\mathrm{T}$, Cabrera $\mathrm{P}$. The primary care visit: what else could be happening? Nurs Res Pract. 2012;2012:720506.

10. Peker I, Alkurt MT. Oral Health Attitudes and Behavior among a Group of Turkish Dental Students. Eur J Dent. 2009; 3: 24-31.

11. Yildiz S, Dogan B. Self reported dental health attitudes and behaviour of dental students in Turkey. Eur J Dent. 2011; 5: 253-259.

12. Kirtiloglu T, Yavuz US. An assessment of oral selfcare in the student population of a Turkish university. Public Health. 2006; 120: 953-957.

13. Powell LV. Caries prediction: a review of the literature. Community Dent Oral Epidemiol. 1998; 26: 361-371.

14. Namal N, Can G, Vehid S, Koksal S, Kaypmaz A. Dental health status and risk factors for dental caries in adults in Istanbul, Turkey. East Mediterr Health J. 2008; 14: 110-118.

15. Ceylan S, Acikel CH, Okcu KM, Kilic S, Tekbas OF, Ortakoglu K. Evaluation of the dental health of the young adult male population in Turkey. Mil Med. 2004; 169: 885-889.

16. Senna A, Campus G, Gagliani M, Strohmenger L. Socio-economic influence on caries experience and CPITN values among a group of Italian call-up soldiers and cadets. Oral Health Prev Dent. 2005; 3: 39-46.

17. Cortes FJ, Nevot C, Ramon JM, Cuenca E. The evolution of dental health in dental students at the 
University of Barcelona. J Dent Educ. 2002; 66: 1203-1208.

18. Levin L, Shenkman A. The relationship between dental caries status and oral health attitudes and behavior in young Israeli adults. J Dent Educ. 2004; 68: 1185-1191.

19. Farago I, Nagy G, Marton S, Tury F, Szabo E, Hopcraft $\mathrm{M}$, et al. Dental caries experience in a Hungarian police student population. Caries Res. 2012; 46: 95-101.

20. Petersen PE, Ogawa $\mathrm{H}$. The global burden of periodontal disease: towards integration with chronic disease prevention and control. Periodontol 2000. 2012; 60: 15-39.
21. Lopez R, Baelum V. Classifying periodontitis among adolescents: implications for epidemiological research. Community Dent Oral Epidemiol. 2003; 31: 136-143.

22. Eres G, Saribay A, Akkaya M. Periodontal treatment needs and prevalence of localized aggressive periodontitis in a young Turkish population. J Periodontol. 2009; 80: 940-944. 